\title{
Field evaluation of different rapeseed mustard genotypes under semi arid conditions of Punjab
}

\author{
GURMAIL SINGH SANDHU, BALKARAN SINGH SANDHU* AND NIRMALJIT SINGH DHALIWAL \\ Krishi Vigyan Kendra, Goneana, SRI MUKTSAR SAHIB (PUNJAB) INDIA \\ (Email : balkaransandhu@gmail.com)
}

\begin{abstract}
Brassica crops are the important source of edible oil in India, but traditional low yielding genotypes should be replaced with the improved genotypes to meet edible oil requirement of the country domestically. A field study was conducted during Rabi 2013-14 and 2014-15 to test the yield response of new genotypes of rapeseed mustards at different locations in Sri Muktsar Sahib district of Punjab. New raya genotype, RLC 3 gave higher average yield ( $15.21 \mathrm{q} / \mathrm{ha})$ as compared to local check RLC 1 (14.8 q/ha). African sarson genotype PC 10 also produced higher average grain yield (16.48 q/ha) as compared to local check $(15.32 \mathrm{q} / \mathrm{ha})$. The incidence of white rust disease was not observed in new genotypes, whereas Alternaria blight incidence was lower as compared to local checks. New genotypes also gave higher per hectare net return as compared to respective local checks. Overall net return from African sarson was better as compared to raya.
\end{abstract}

Key Words : Alternaria blight, Brassica, Genotype, White rust,Yield

View Point Article : Sandhu, Gurmail Singh, Sandhu, Balkaran Singh and Dhaliwal, Nirmaljit Singh (2016). Field evaluation of different rapeseed mustard genotypes under semi arid conditions of Punjab. Internat. J. agric. Sci., 12 (1) : 42-46.

Article History : Received : 17.07.2015; Revised : 19.11.2015; Accepted : 01.12.2015

\footnotetext{
* Author for correspondence
} 